\title{
IMPACT OF COVID-19 ON ONLINE SHOPPING -A CASE STUDY
}

\author{
Sahana Shetty ${ }^{1}$, Dr. Ramesh Pai ${ }^{2}$ \\ 1 Research Scholar, Srinivas University, Mangalore - 575001, India \\ ${ }^{2}$ Research Guide, Srinivas University, Mangalore - 575001, India
}

Article DOI: https://doi.org/10.36713/epra7063

DOI No: 10.36713/epra7063

\begin{abstract}
The covid 19 pandemic is a major tragedy across the world, which has affected the lives of people all around the world. It has significantly affected the economy in a global level by having an impact on the business industries. Where many business firms had a really hard hit, some other business firms had experienced huge increase in sales through their online platform. The lockdown in the initial period of the pandemic had a large impact on e-commerce especially due to the restrictions across the borders and delay in the order deliveries. Social networks played a pivotal role in sharing the information and also making choices of the products. The online stores need to understand the current trends of online shopping to cope up in this highly competitive world and identify the suitable methods to convert every challenge into an opportunity.

This study explores the impact of covid 19 pandemic on the online shopping platform and the behavior of consumers. The study is based on an empirical research method. The data for the study are collected from 91 respondents through a self-designed questionnaire through stratified random sampling method and the sample includes online shoppers from Dakshina Kannada district.
\end{abstract}

KEYWORDS: Online shopping, Covid 19, Consumer behavior, E-sellers.

\section{INTRODUCTION}

The outbreak of Covid 19 has created challenges and opportunities for the online sellers all around the world. The orders from the government to stay at home and to maintain social distancing everywhere has made online shopping, the most preferred method of making purchases to a major share of population of the country. Due to this reason, some business firms explored e-commerce for the first time and trying their best to attract the customers to their new online stores. According to reports, the online shopping websites is likely to increase its market share up to 100 billion dollars by 2024 (Choudhury, 2021). As more and more people turn to ecommerce, it has reduced the brick and motor shopping and increased the online shopping.

But on the other end, some buyers have questioned about the safety of taking the orders from the delivery boys. The whole process of buying online up to the delivery of the product takes minimum of three to four days depending on the place of seller and the buyer. Experts from WHO say that (as mentioned in their website), risk of virus that cause covid-19 on a package that gets exposed to different temperature during its transit is very low.

\section{OBJECTIVES}

1. To understand the current trend of online shopping.

2. To know impact of Covid 19 pandemic on online stores.

3. To know the customer behavior before and during Covid 19 towards online shopping. 


\section{RESEARCH METHODOLOGY}

This study includes primary data and secondary data. The secondary data are collected from journals, websites, books and reports. The primary data have been collected through online survey with the help of a structured questionnaire and in-depth personal interviews over the telephone.

\section{SAMPLING DESIGN}

The primary data are gathered through online survey with the help of a structured questionnaire from 91 respondents under convenience random sampling method where only online shoppers of Dakshina Kannada district were selected. The study also includes in-depth personal interviews with online shoppers over the telephone.

\section{STATISTICAL DESIGN}

The collected data are coded, tabulated analyzed, interpreted using tables, charts and graphs. Descriptive statistical tool-Findings of the study is based on percentage analysis method.

\section{GEOGRAPHICAL AREA}

The respondents for the study have been selected from Dakshina Kannada District.

\section{GROWTH IN THE USAGE OF INTERNET AND E-COMMERCE IN INDIA}

In the first quarter of 2019, India reported the highest share of growth in users of internet (Keelery, 2020). Access to internet is a pre-requisite to shop products online. The fast-growing digital literacy in India is itself a proof of people adopting the culture of e-commerce even before the covid 19 pandemic. Many earlier studies on e-commerce also stated that the online shopping is increasing at a rapid rate. The awareness of internet use has led to the increase in the number of smartphone users in rural and urban areas too (Patel, 2015). Good data connectivity with reduced data price by Jio and other telecom providers has further resulted in more people switching to online mode. India has a fast-growing online population standing next to china (Ecommerce industry in India, 2018).

India is the second largest online market in the world after China. E-commerce in India is expected to have a prospective growth if the government is able to provide consumer protection, prevention of fraud and also legal security for online shopping activities (D Mahipal, 2018).

E-commerce in global level comprises of more than 13\% of total revenue in retail sales in the year 2019 (Figure 1). India and Indonesia are expected to have a fast growth in the retail sector of e-commerce from 2018-2022 (Chow, 2021).

\section{ECONOMIC IMPACT OF COVID 19 IN INDIA}

In order to reduce the spreading of coronavirus in India, government took various measures which declined the mobility of people to a great extent. Government of India under Prime minister Narendra Modi, ordered a nationwide lockdown on $24^{\text {th }}$ March, 2020 which extended till $31^{\text {st }}$ May, 2020. There was a complete shutdown of all the shopping malls and shopping centers. People were not allowed to step out of their homes and all transportation services were also suspended. Food shops, petrol pumps, banks, ATMs and other essentials were an exemption. Despite of the relaxations, employees were encouraged to work from home and conducted meetings and conferences in online mode. Educational institutions also continued to conduct classes from home through online platforms. People's need for luxuries reduced and need for necessities increased. During the initial days of covid 19 pandemic, e-commerce platforms also was allowed to deliver only the essential commodities. According to a survey conducted by the Statista Research Department (Department, Statista, 2021) in April 2020, majority of the respondents went to the nearest local shops to purchase the nonessential commodities and around 26 percent used the online platforms to buy the items. In expectation of further lockdown and scarcity of stock of supplies, people also engaged in panic buying.

Post lockdown, though the purchase rate increased slightly, there was less improvement in online shopping due to the rising rate of unemployment and the salary cut among the employees. Unemployment rate raised nearly up to $24 \%$ in April 2020. This resulted in the reduction of disposable income. The spending capacity of people in India came down leading to less demand for non-essential items.

\section{CUSTOMER ATTITUDE TOWARD ONLINE SHOPPING DURING THE} PANDEMIC

Despite the growing usage of internet and rise in the e-commerce sector, many Indian consumers still prefer to shop in physical stores so that they can touch and study the size, quality and content of the products before they decide to buy. But the covid 19 pandemic has forced majority of such consumers to buy products from online stores. People were left with no choice during the days of lockdown. And even after the relaxation 
people chose to buy groceries and certain other essentials and also non-essential commodities from online stores to avoid the crowd and maintain social distancing.

\section{CURRENT TRENDS IN ONLINE SHOPPING}

Online shopping in India will definitely stay and is not stoppable in the years to come (Abhishek Chilka, 2018). The first item ever ordered online was a book in Amazon in the year 1995. 25 years later, today there has been a significant revolution in the ecommerce sector. From its limited capabilities in the beginning, today there has been a great transformation in the services provided like customization, improved return policies, various kinds of payment methods and so on. Thus, people have every reason to opt online shopping. The latest trends in online shopping are as follows:

a) Growing Mobile Shopping: Increase in the use of smart phones has made consumers to shop for their preferred items from anywhere and anytime. People also browse for the products and research on it through their mobile phones before making a purchase decision.

b) Increase of Young Consumers: Most of the studies show that, though there is a overall shift consumers to online shopping from all age groups, the younger generation between age gap of 18-34 are purchasing more online products during the pandemic.

c) Multiple payment methods: Companies offer a wide variety of payment methods to the customers where customers can opt for their convenient method of payments. Customers can even save their payment details on the site and can quickly make a purchase during the checkout process.

d) Role of Social Media: Social medias are continuously upgrading their features to meet the needs of its users. One such feature is linking of online stores within the sites of social media. For instance, Facebook has introduced a "Buy" button and Instagram has introduced "Checkout".

e) Environmental Consciousness: Today people are becoming more responsible and are more conscious about the environment. Therefore, online sellers are taking steps to create environmentally friendly products.

f) Voice Commerce: Customers can research for their preferred items using devices which are assisted by voice like Google Home and Amazon Echo.

g) Chatbots: It is a tool to communicate through text chats or voice commands. ELIZA is the first chatbot programmed in the year 1960. Companies use these devices to gather more data and improve the service to their customers by providing quick responses.

h) Artificial Intelligence (AI): Today, there are various AI tools which helps the companies to provide a personalized experience for the online customers by automating the online shopping platforms and quickly responding to the customer queries.

i) Augmented Reality: The major limitation of online shopping platform is that the consumer cannot see the product making it difficult to take purchase decision. The AR technology enables the buyers to visualize the commodity by superimposing the digital image or sound over real-life scenes.

j) Personalization: Online shopping websites are continuously working on personalizing the shopping experience to keep the customers satisfied. It includes personalization of messages and also giving the right kind of information to every customer.

k) Subscription Ecommerce: Subscription ecommerce takes place when the customers repeatedly purchase the same product from the same online store. If the online stores want the customers to repeat their purchases, they must provide good shopping experience and also ensure the quality of the commodities.

1) Visual Commerce: Visual commerce is the next level of ecommerce which incorporates interactivity, videos, augmented reality etc., instead of only displaying the photos of the products in the shopping websites.

m) Omnichannel Shopping: Omnichannel means maintaining uniformity in customer experience. It is a multichannel approach that provides a better experience to the customers whether they shop online from their laptop or a mobile phone or in a physical store by designing their website in such a way that it is consistent with a mobile app or any other means of shopping.

n) Customer feedback: Collecting feedback from the customers gives the online sellers an insight to understand the customer perceptions and make better plans for the future.

\section{RESULTS}

Information collected from the respondents through the questionnaire is analyzed and interpreted as follows:

- Table 1 shows that 61.54 percent of the respondents are female and 38.46 percent of respondents are male. The majority of the respondents are in the age group of 20 - 29 and are undergraduates and. 49.45 percent of the respondents are professionals. The monthly income of 32.96 percent of respondents is between 20001 - 30000 . 
- Figure 2 shows that $16.7 \%$ of the respondents buy online products very often and $50 \%$ of the respondents buy quite often and $33.33 \%$ of the respondents rarely buy online products.

- Figure 3 shows that $63.64 \%$ of respondents spent approximately less than $₹ 5000,16.48 \%$ of respondents spent ₹5000 - ₹ $15000,13.19 \%$ spent ₹ 15001 - ₹25000 and 4.40\% spent ₹25001 - ₹50000 and only 3.30\% spent above ₹50000 on online shopping in the year 2019.

- $\quad$ Figure 4 shows that $56.04 \%$ of respondents spent less than ₹5000, 23.07\% of respondents spent ₹5000 ₹ $15000,9.89 \%$ spent $₹ 15001$ - ₹25000 and 1.09\% spent ₹25001 - ₹50000 and 9.89\% spent above ₹50000 on online shopping in the year 2020.

- Figure 5 shows that $63.19 \%$ of the respondents prefer physical mode of shopping and $36.81 \%$ of the respondents prefer online mode of shopping to buy groceries, clothing, cosmetics, home appliances, electronics and fashion accessories.

- Figure 6 shows that the online shopping for clothing is decreased by $12.82 \%$, shoes or sandals by $10 \%$ and home appliances by $27.27 \%$ during covid-19 pandemic in the year 2020. By the online shopping for groceries is increased by $33.33 \%$, wallets or handbags by $16.67 \%$, fashion accessories by $16.67 \%$, cosmetics by $18.18 \%$. There has been no change in the online purchase of electronics before and after covid-19 pandemic. But the overall online purchase is reduced by $3.16 \%$.

\section{SUGGESTIONS}

- The constant growth in the internet usage from past few years especially by younger generation is a sign of technological development among the people. This must be efficiently utilized by the online business companies.

- It is found that many Indian consumers still prefer to shop from physical stores. To convert them to online mode, online sellers have to make use of latest technologies like Augmented Reality, Chatbots, Omnichannel, Voice search, Visual commerce, Personalization features etc., to give more convenience to the customers.

- Since the smart phone usage is increasing, the online stores have to optimize their sites to give a best experience to the customers while shopping

- $\quad$ in their mobile phones.

- Online stores must make the payment procedure very simple and at the same time take utmost care in providing security to their financial and other personal details.

- Online stores must use the feedback of the customers to continuously improve and update their shopping websites.

- The online stores must also take suitable measures to safely deliver the package from its source to the destination so that the customers will be relieved of their health \& safety during this pandemic period.

- Online stores must increase their social media marketing since it is the means of reaching a large share of young consumers.

\section{CONCLUSION}

The Covid-19 pandemic is surely a boon to the online sellers provided they update themselves with the latest technologies and take suitable measures to deal with the current situation. The online sellers must understand the current trends of online shopping and make required corrections. Though many earlier studies stated that the Covid-19 had a positive impact on the online shopping sector, it has proved to be partially true in this study. This study has found that while some online sellers who sell groceries, fashion accessories, cosmetics etc., are doing great, some online stores who sell home appliances, clothing, electronics are not doing well. The reason for this may be the fear of spreading of corona virus, or may be the rising unemployment rate and decreasing income of the people in Dakshina Kannada district. Online stores which did not perform well has to take necessary measures to improve the overall online shopping sector.

\section{AREA FOR FURTHER RESEARCH}

Further study can be taken with a larger share of sampling. The present study only studies the impact of covid-19 on online shopping sector till the end of 2020 or early 2021 . But since the pandemic period has not ended yet, there are more changes to happen in coming days to online shopping. The research can be further continued in this area. 
EPRA International Journal of Environmental Economics, Commerce and Educational Management Journal DOI: 10.36713/epra0414 |ISI I.F Value: 0.815|SJIF Impact Factor (2021): 7.743

Volume: 8 | Issue: 5 | May 2021

15. FIGURES AND TABLES

Table 1: The personal demographic profile of the respondents

\begin{tabular}{|c|c|c|c|}
\hline Respondent's & Demographics & \begin{tabular}{|l} 
No \\
respondents
\end{tabular} & Percentage \\
\hline \multirow{3}{*}{ Gender } & Male & 56 & 61.54 \\
\hline & Female & 35 & 38.46 \\
\hline & Total & 91 & 100 \\
\hline \multirow{6}{*}{ Age } & Less than 20 & 4 & 4.40 \\
\hline & $20-29$ & 45 & 49.45 \\
\hline & $30-39$ & 15 & 16.48 \\
\hline & $40-49$ & 21 & 23.08 \\
\hline & 50 and above & 6 & 6.59 \\
\hline & $\begin{array}{r}\text { Total } \\
\end{array}$ & 91 & 100 \\
\hline \multirow{7}{*}{ Education } & Less than SSLC & 1 & 1.10 \\
\hline & SSLC & 2 & 2.20 \\
\hline & PUC & 1 & 1.10 \\
\hline & Bachelor's degree & 42 & 46.15 \\
\hline & Master's degree & 39 & 42.86 \\
\hline & Professional degree & 6 & 6.59 \\
\hline & Total & 91 & 100 \\
\hline \multirow{7}{*}{ Occupation } & Student & 30 & 32.97 \\
\hline & Homemaker & 3 & 3.30 \\
\hline & \begin{tabular}{|l} 
Business \\
\end{tabular} & 6 & 6.59 \\
\hline & Professional & 45 & 49.45 \\
\hline & Retired & 1 & 1.10 \\
\hline & Other & 6 & 6.59 \\
\hline & Total & 91 & 100 \\
\hline \multirow{7}{*}{ Income } & Less than 10000 & 21 & 23.08 \\
\hline & $\mid 10001-20000$ & 21 & 23.08 \\
\hline & $20001-30000$ & 30 & 32.96 \\
\hline & $30001-40000$ & 3 & 3.30 \\
\hline & \begin{tabular}{|l|}
$40001-50000$ \\
\end{tabular} & 1 & 1.10 \\
\hline & Above 50000 & 15 & 16.48 \\
\hline & Total & 91 & 100 \\
\hline
\end{tabular}

Figure 2: Frequency of buying products online

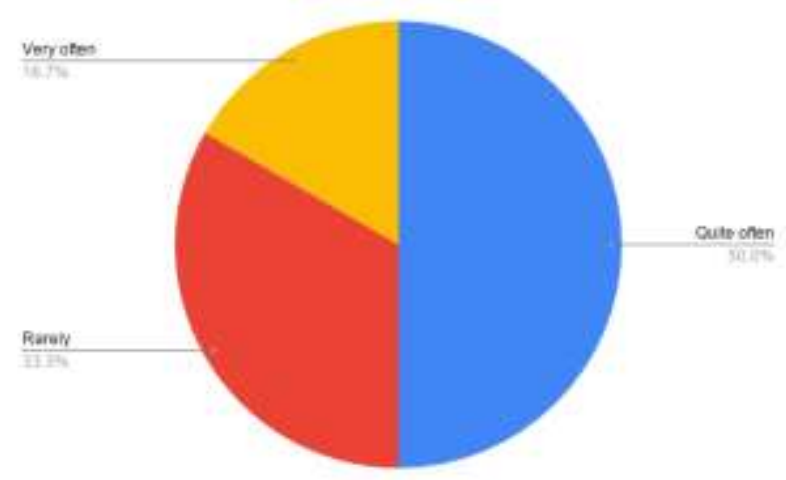


EPRA International Journal of Environmental Economics, Commerce and Educational Management Journal DOI: 10.36713/epra0414 |ISI I.F Value: 0.815|SJJF Impact Factor (2021): 7.743

ISSN: $2348-\mathbf{8 1 4 X}$ Volume: 8 | Issue: 5 | May 2021

Figures 3 \& 4: Approximate amount spent on online shopping in the year 2019 and 2020
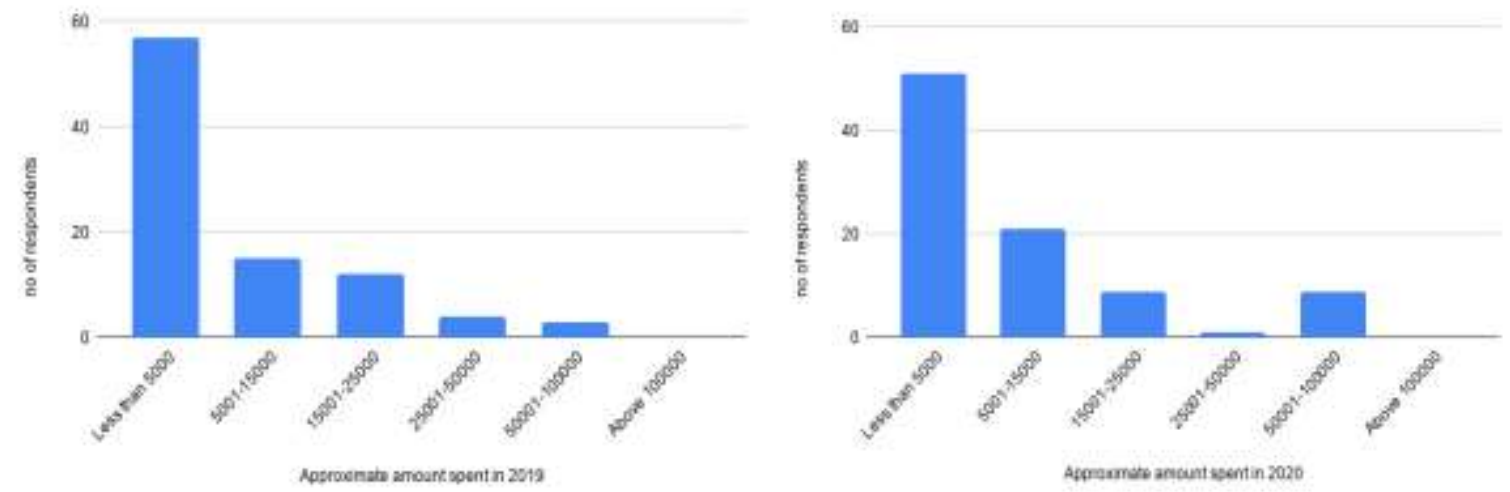

Figure 5: Preferred mode of shopping for the following items

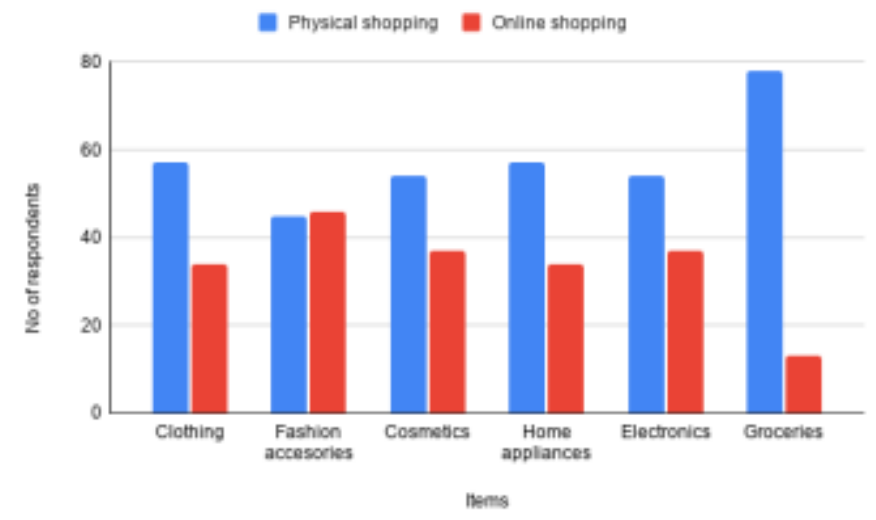

Figure 6: Table shows the items bought online before Covid-19 pandemic and during Covid-19 pandemic

\begin{tabular}{|l|c|c|c|}
\hline Items bought & $\begin{array}{c}\text { Before Covid-19 } \\
\text { pandemic (2019) }\end{array}$ & $\begin{array}{c}\text { During Covid-19 } \\
\text { pandemic (2020) }\end{array}$ & $\begin{array}{c}\text { Rate of increase or } \\
\text { decrease }\end{array}$ \\
\hline Clothing & 78 & 63 & $-12.82 \%$ \\
\hline Wallets or Handbags & 18 & 21 & $+16.67 \%$ \\
\hline Fashion accesories & 36 & 42 & $+16.67 \%$ \\
\hline Cosmetics or Beauty products & 33 & 39 & $+18.18 \%$ \\
\hline Shoes or Sandals & 30 & 27 & $-10 \%$ \\
\hline Electronic items & 48 & 48 & 0 \\
\hline Home appliances & 33 & 24 & $-27.27 \%$ \\
\hline Groceries & 9 & 12 & $+33.33 \%$ \\
\hline Total & $\mathbf{2 8 5}$ & $\mathbf{2 7 6}$ & $-\mathbf{3 . 1 6 \%}$ \\
\hline
\end{tabular}

\section{REFERENCES}

1. Abhishek Chilka, S. C. (2018). Study on Recent Trends in Online Shopping in India. International Journal of Scientific \& Engineering Research, 9(2), 30-33.

2. Alina Butu, I. S. (2020). The Impact of COVID-19 Crisis upon the Consumer Buying Behavior of Fresh Vegetables Directly from Local Producers. Case Study: The Quarantined Area of Suceava County, Romania. International Journal of Environmental Research and Public Health, 17(15), 1-24. doi:https://doi.org/10.3390/ijerph17155485

3. Anupam Sharma, D. J. (2020). Changing Consumer Behaviours towards Online Shopping - An Impact of Covid 19. Academy of Marketing Studies Journal, 24(3).

4. Choudhury, S. (2021, March 30). Grabon. Retrieved from https://blog.grabon.in/: https://blog.grabon.in/best-onlineshopping-sites/

5. Chow, J. (2021, March 9). Online Shopping, E commerce and Internet Shopping (2021). Retrieved from www.webhostingsecretrevealed.net: $\quad$ https://www.webhostingsecretrevealed.net/blog/ecommerce/online-shoppingecommerce-and-internet-statistics-2020-you-should-

know/\#: :text=Retail\%20eCommerce\%20will\%20account\%20for,members\%20in\%20the\%20United\%20States. 
6. D Mahipal, K. S. (2018). E-commerce Growth in India: A Study of Segments Contribution. Academy of Marketing Studies Journal, 22(2). Retrieved from https://www.abacademies.org/articles/ecommerce-growth-in-india-a-study-ofsegments-contribution-7239.html

7. Department, S. R. (2021, March 24). E-Commerce. Retrieved from www.statista.com: https://www.statista.com/statistics/1115652/india-coronavirus-post-lockdown-purchase-ecommerce/\#: :text=According\%20to\%20a\%20survey\%20about,sites\%20for\%20essentials\%20supplies\%20only.

8. Department, S. R. (2021, March 19). Economy. Retrieved from www.statista.com: https://www.statista.com/statistics/1111487/coronavirus-impact-on-unemploymentrate/\#: :text=COVID\%2D19\%20impact\%20on\%20unemployment\%20rate\%20in\%20India\%202020\%2D2021\&text=I $n \% 20 J a n u a r y \% 202021 \% 2 \mathrm{C} \% 20$ India\%20saw,improvement\%20from\%20the\%20previous\%20month.\&t

9. Department, S. R. (2021, March 25). Shopping Behavior. Retrieved from www.statista.com: https://www.statista.com/statistics/1119220/india-share-of-panic-buyers-after-coronavirusoutbreak/\#: : :text=People\%20engaged\%20in\%20panic\%20buying\%20due\%20to\%20COVID\%2D19\%20India\%20202 O\&text=According\%20to\%20a\%20survey\%20by, because\%20of\%20the\%20coronaviru

10. Department, S. R. (2021, March 19). Statista. Retrieved from www.statista.com: https://www.statista.com/statistics/1111487/coronavirus-impact-on-unemployment-rate/

11. (2018). Ecommerce industry in India. redseer. Retrieved from https://redseer.com/reports/ecommerce-industry-inindial

12. Keelery, S. (2020, July 7). Statista. Retrieved from www.statista.com: https://www.statista.com/topics/2157/internetusage-in-indial

13. Kwiat, A. (2020, May Thursday). Case Study: The Impact of Coronavirus on Digital Marketing \& Ecommerce. Illinois Technology Association. Retrieved from https://www.illinoistech.org/news/509975/Case-Study-The-Impact-ofCoronavirus-on-Digital-Marketing--Ecommerce.htm

14. Ms.K.Susmitha. (2020). Impact of COVID 19 on E-Commerce. Journal of Interdisciplinary Cycle Research, XII(IX), 1161-1165. doi:DOI: 10.13140/RG.2.2.20236.85127

15. Muhammad Kashif, A.-U.-R. M. (2020). COVID-19 IMPACT ON ONLINE SHOPPING. International Journal of Medical Science in Clinical Research and Review, 03(4), 325-330.

16. Naveen Donthu, A. G. (2020). Effects of COVID-19 on business and research. Journal of Business Research, 117, 284289. doi:https://doi.org/10.1016/j.jbusres.2020.06.008

17. Patel, D. S. (2015). Evolution of Online Shopping in India and its Unparallel Growth. International Journal for Research in Management and Pharmacy, 4(3), 24-33.

18. Susanne Schwarzl, M. G. (2015). Online marketing strategies: The future is here. Journal of International studies, 8(2), 187-196. doi:http://dx.doi.org/10.14254/2071-8330.2015/8-2/16

19. Van Kien Pham, T. H. (2020). A study on the COVID-19 awareness affecting the consumer perceived benefits of online shopping in Vietnam. Cogent Business \& Management, 7(1), 116-131. doi:https://doi.org/10.1080/23311975.2020.1846882 